\title{
Dampak penerapan model pembelajaran kooperatif tipe spontaneous group discussion dan numbered heads together terhadap hasil belajar siswa (The impacts of spontaneous group discussion on learning outcomes)
}

\author{
Endar Dwi Yulianti', Budi Santoso ${ }^{2 *}$ \\ ${ }^{1,2}$ Program Studi Pendidikan Manajemen Perkantoran, \\ Fakultas Pendidikan Ekonomi dan Bisnis, Universitas Pendidikan Indonesia, \\ J. Dr. Setiabudhi, No. 229 Bandung, Jawa Barat Indonesia \\ Email: budisantoso@upi.edu
}

\begin{abstract}
ABSTRAK
Salah satu kunci keberhasilan dalam mendongkrak hasil belajar siswa adalah pemilihan model pembelajaran yang tepat sesuai dengan mata pelajarannya. Lewat artikel ini kita dapat melihat dampak penerapan model pembelajaran tipe kooperatif spontaneous group discussion dengan model pembelajaran numbered heads together terhadap hasil belajar 72 siswa pada mata pelajaran kearsipan kompetensi dasar mengelola sistem kearsipan kelas X Administrasi Perkantoran di sebuah SMK Negeri di Kabupaten Karawang. Lewat kuasi eksperimen, didapat bahwa model pembelajaran spontaneous group discussion jauh lebih efektif dibandingkan dengan model pembelajaran numbered heads together khususnya pada mata pelajaran kearsipan kompetensi dasar mengelola sistem kearsipan. Melalui hasil penelitian, model pembelajaran spontaneous group discussion dapat menjadi rujukan bagi guru dalam mendongkrak hasil belajar siswa khususnya pada mata pelajaran tersebut
\end{abstract}

Kata Kunci: spontaneous group discussion, numbered heads together , hasil belajar

\begin{abstract}
One key to success in raising students' learning outcomeis by choosing an appropriate learning model for the subject. Through this article,we can see impact of application of spontaneous group discussion and numbered heads together cooperative learning models toward learning outcome of 72 students in archival subject: basic competency of archival system in grade X on Office Administration program in one of public vocational school in Karawang Regency. Through a quasiexperimental, it was obtained that spontaneous group discussion learning model was more effective than numbered heads together learning model especially on archival subject: basic competency of archival system. Through the findings of research, spontaneous group discussion learning model can become teachers' reference in raising students' learning outcome especially on that subject.
\end{abstract}

Keywords: spontaneous group discussion, numbered heads together, learning outcome

\section{PENDAHULUAN}

Pendidikan adalah sarana terpenting untuk menciptakan kualitas sumber daya manusia yang unggul di teng ah persaingan dunia kerja yang semakin meningkat. Dalam mencetak sumber daya yang unggul, tentunya pihak sekolah perlu menciptakan sistem

* Corresponding author

Copyright (C) 2017, EISSN 2656-4734 
pembelajaran yang baik. Hasil dari sistem pembelajaran yang baik akan menghasilkan hasil belajar yang baik sebagai indikator keberhasilan dari sistem pembelajaran.

Ada berbagai upaya untuk meningkatkan hasil belajar siswa, salah satu upaya tersebut adalah lewat penerapan model pembelajaran. Model pembelajaran memiliki peran yang penting sebagai dasar maupun rancangan dalam pelaksanaan proses pembelajaran. Kedudukan model pembelajaran amatlah penting, lewat penerapan model pembelajaran yang tepat sesuai dengan mata pelajaran akan memudahkan siswa dalam menyerap pelajaran sehingga dapat mencapai nilai KKM (Kriteria Ketuntasan Minimal).

Terdapat berbagai model pembelajaran yang dikenal dalam dunia pendidikan. Salah satu model pembelajaran yang sering dipakai dalam dunia pendidikan adalah model pembelajaran kooperatif tipe spontaneous group discussion. Model pembelajaran kooperatif memiliki tipe seperti: (1) saling ketergantungan positif, (2) interaksi tatap muka, (3) akuntabilitas individual, dan (4) keterampilan untuk menjalin hubungan antara pribadi atau keterampilan sosial yang secara sengaja diajarkan (Abdurrahman dan Bintoro, 2000, dalam Nurhadi, 2003). Model pembelajaran ini sangat cocok terhadap teori pembelajaran konstruktivisme sosial Vygotsky yang menekankan pada pemahaman siswa didapat dari konstruksi diri lewat interaksi sosial dengan lingkungan di sekitarnya.

Spontaneous group discussion merupakan ragam dari pelaksanaan model pembelajaran kooperatif. Spontaneous group discussion merupakan metode diskusi kelompok yang tidak direncanakan sebelumnya, tetapi dilaksanakan secara spontan dan sederhana (Huda, 2011). Huda (2011) juga menjelaskan bahwa dalam menyelenggarakan tipe spontaneous group discussion ini guru dapat menyusun langkah-langkah seperti: 1) Meminta siswa untuk berkelompok; 2) Siswa berdiskusi tentang sesuatu, yaitu soal atau permasalahan tentang materi pelajaran yang diberikan oleh guru kepada siswa; 3) Guru memanggil kelompok satu persatu; dan 4) Siswa mempresentasikan hasil diskusi di depan kelas. Dapat disimpulkan bahwa model pembelajaran ini menekankan interaksi sosial, salah satunya lewat interaksi antar teman sebaya dalam kelompok kecil untuk memahami suatu pelajaran.

Guru atau pihak sekolah perlu memberikan variasi model pembelajaran sesuai mata pelajaran agar siswa tidak merasa jenuh dan lebih memahami pembelajaran. Pembelajaran dengan model pembelajaran yang kurang bervariasi dirasa kurang optimal dalam mendongkrak hasil belajar siswa. Misalnya, seperti di sebuah SMK Negeri di Kabupaten Karawang yang masih menggunakan model pembelajaran numbered heads together untuk mengajar mata pelajaran kearsipan. Akan tetapi, nilai rata-rata hasil belajar mata pelajaran kearsipan dari beberapa kelas menunjukkan hasil yang belum optimal seperti yang ditunjukkan dalam tabel berikut.

\section{Tabel 1} Nilai Rata - Rata Mata Pelajaran Kearsipan
Kompetensi dasar Sistem Kearsipan

Tahun ajaran 2015/2016

\begin{tabular}{|c|c|c|c|c|}
\hline \multirow{2}{*}{ Kelas } & \multirow{2}{*}{ KKM } & \multicolumn{3}{|c|}{ Nilai Rata - Rata Kompetensi Dasar } \\
\cline { 3 - 5 } & & Pengetahuan & Keterampilan & Sikap \\
\hline X AP 1 & 75 & 70,04 & 75,69 & 82,00 \\
\hline X AP 2 & 75 & 73,11 & 73,14 & 82,00 \\
\hline X AP 3 & 75 & 69,76 & 70,04 & 82,00 \\
\hline X AP 4 & 75 & 69,11 & 70,42 & 82,00 \\
\hline X AP 5 & 75 & 72,48 & 71,60 & 82,00 \\
\hline \multicolumn{2}{|c|}{ Rata-rata } & 70,90 & 72,18 & 82,00 \\
\hline
\end{tabular}

Sumber : Arsip SMK Negeri X Karawang Tahun 2016) data diolah 
Mencermati data empiris pada table 1 di atas, dapat disimpulkan bahwa rata-rata nilai siswa khususnya pada aspek pengetahuan dan keterampilan masih belum optimal. Hal ini dapat dilihat dari rata-rata nilai pengetahuan dan keterampilan yang masih di bawah standar KKM, yaitu 75. Permasalahan ini perlu segera ditangani oleh pihak sekolah dalam meningkatkan hasil belajar siswa sebagai standar kompetensi dengan memberikan model pembelajaran yang tepat

Berdasarkan fenomena di atas, penulis tertarik melakukan penelitian untuk melihat dampak dari penerapan model pembelajaran kooperatif tipe spontaneous group discussion dan numbered heads together terhadap hasil belajar siswa pada mata pelajaran kearsipan. Berikut akan dijelaskan mengenai paparan teori atau kajian pustaka yang berkaitan dengan variabel, metode penelitian yang digunakan, hasil penelitian di lapangan, serta kesimpulan dan saran penelitian.

\section{TINJAUAN PUSTAKA}

\section{Model Pembelajaran Kooperatif Tipe Spontaneous Group Discussion}

Terdapat beberapa definisi mengenai model pembelajaran kooperatif tipe spontaneous group discussion merujuk pendapat para ahli. Agus (2010) menjelaskan bahwa model pembelajaran kooperatif merupakan konsep yang lebih luas meliputi semua jenis kerja kelompok termasuk bentuk-bentuk yang dipimpin oleh guru atau diarahkan oleh guru. Model pembelajaran kooperatif juga menekankan kerja sama antar siswa dalam timtim kecil yang diarahkan oleh guru untuk mencapai tujuan pembelajaran (Slavin, dalam Isjoni, 2010).

Adapun model pembelajaran kooperatif tipe spontaneous group discussion merupakan model pembelajaran yang menekankan lima elemen dalam pelaksanaan diskusi kelompok, yaitu interdependensi positif, akuntabilitas individu, interaksi promotif, keterampilan social, dan pemrosesan kelompok (Huda, 2011). Huda (2011) menjelaskan bahwa dalam pelaksanaan pembelajaran berbasis model spontaneous group discussion, guru dapat melakukan langkah-langkah seperti, membentuk kelompok-kelompok, mengajak kelompok tersebut untuk mendiskusikan permasalahan pembelajaran, dan kelompok tersebut mempresentasikan secara acak atas hasil diskusi pembelajaran tersebut.

Adapun berbagai manfaat dalam pelaksanaan model pembelajaran ini, seperti dapat meningkatkan aktivitas belajar siswa, menumbuhkan sikap berani dan percaya diri siswa dalam mengkomunikasikan ide, gagasan dan pendapat baik secara lisan maupun secara tertulis, dan model pembelajaran lebih menarik, menyenangkan dan kreatif serta meningkatkan aktivitas belajar siswa (Huda, 2011).

\section{Model Pembelajaran Kooperatif Tipe Numbered Head Together}

Ada beberapa konsep mengenai model pembelajaran numbered head together. Kagan (1993) menjelaskan bahwa model pembelajaran numbered heads together menekankan pada model pembelajaran kooperatif struktural, yang menekankan pada struktur-struktur khusus yang dirancang untuk mempengaruhi pola interaksi siswa.

Dalam pelaksanaan model pembelajaran ini, guru perlu menyediakan beberapa komponen seperti, penomoran, pengajuan pertanyaan, berpikir bersama, dan pemberian jawaban pada masing-masing peserta didik (Kagan, 1993). Adapun langkah-langkah yang dapat dilakukan untuk melaksanakan model pembelajaran ini diantaranya dengan persiapan, pembentukan kelompok, pemberian buku paket atau buku panduan pada setiap kelompok, pendiskusian masalah, memanggil nomor anggota kelompok atau pemberian jawaban, hingga penarikan kesimpulan (Kagan, 1993). 
Ada beberapa kelebihan dari model pembelajaran numbered head together. Kagan (1993) memaparkan bahwa terdapat beberapa kegunaan dari penelitian ini diantaranya meningkatkan rasa harga diri menjadi lebih tinggi, memperbaiki kehadiran, rasa penerimaan terhadap individu menjadi lebih besar, perilaku mengganggu menjadi lebih kecil, konflik antara pribadi berkurang, pemahaman yang lebih mendalam, dan meningkatkan kebaikan budi, kepekaan dan toleransi terhadap teman sebaya.

\section{Hasil Belajar}

Hasil belajar adalah hasil yang diperoleh berupa kesan-kesan yang mengakibatkan perubahan dalam diri individu sebagai hasil dari aktivitas dalam belajar (Djamarah, 1996). Hasil belajar juga merupakan seluruh kecakapan dan segala hal yang diperoleh melalui proses belajar mengajar di sekolah yang dinyatakan dengan angka dan diukur dengan menggunakan tes hasil belajar (Sudjana, 2009).

Dimyati (2006) menjelaskan bahwa hasil belajar merupakan satu interaksi tindakan belajar dan tindakan mengajar. Ada berbagai faktor yang turut mempengaruhi pencapaian hasil belajar siswa di sekolah. Bloom dalam Sudjana (2004) menjelaskan ada 2 faktor yang mempengaruhi hasil belajar siswa, yaitu faktor internal dan faktor eksternal. Faktor internal terdiri dari kemampuan peserta didik, minat dan perhatian, sikap dan kebiasaan belajar, ketekunan, sosial ekonomi, fisik dan psikis. Faktor eksternal terdiri dari guru, kurikulum, lingkungan, media, peserta didik, dan model pembelajaran. Bloom dalam Sudjana (2004) menjelaskan ada beberapa ranah atau aspek dalam mengukur capaian hasil belajar. Ranah tersebut yaitu, ranah afektif, psikomotorik, dan kognitif.

\section{METODOLOGI}

Untuk mengetahui dampak dari penerapan model pembelajaran spontaneous group discussion dan numbered heads together terhadap hasil belajar siswa maka peneliti telah melakukan penelitian dengan metode penelitian kuasi eksperimen non equivalent control group design dengan menggunakan dua kelompok kelas yang memiliki kemampuan akademik yang sama berdasarkan observasi sebelumnya. Kelas eksperimen akan diterapkan model pembelajaran spontaneous group discussion, sedangkan pada kelas kontrol akan diterapkan model pembelajaran numbered head together.

Penelitian ini dilakukan di salah satu SMK Negeri di Kabupaten Karawang kelas X Administrasi Perkantoran. Adapun kelas yang dipilih sebagai kelas eksperimen dan kelas kontrol adalah kelas X AP 1 dan X AP 2 karena memiliki rata-rata hasil belajar yang relatif sama. Kelas X AP-1 dan X AP-2 memiliki jumlah siswa sebanyak 36 siswa.

Bentuk instrument atau soal yang diberikan berupa pilihan ganda untuk melihat pemahaman atau kompetensi siswa pada mata pelajaran kearsipan kompetensi dasar mengelola sistem kearsipan sebanyak 30 soal. Tes diberikan 2 jenis, yaitu pre test dan post test. Sebelum soal atau instrument tersebut diujikan, instrumen tersebut perlu diuji melalui uji validitas. Setelah melalui uji validitas, instrumen perlu diuji reliabilitasnya, diuji tingkat kesukarannya, dan diuji daya pembeda antar instrumennya.

Setelah instrumen tersebut diuji, maka instrumen tersebut dapat dibagikan pada kelas pre test dan post test dan diolah. Hal pertama yang dilakukan adalah melakukan uji normalitas untuk mengetahui apakah suatu distribusi data bersifat normal atau tidak. Kedua, dengan melakukan uji homogenitas untuk memeriksa apakah data yang diperoleh pada penelitian mempunyai variansi yang homogen atau tidak. Ketiga, dengan melakukan uji-t untuk mengetahui ada tidaknya perbedaan hasil belajar antara kelompok kelas eksperimen dengan kelas kontrol. Keempat, dengan uji Gain untuk mengetahui peningkatan kualitas hasil belajar peserta didik pada kelas eksperimen dan kelas kontrol 
dilihat dari nilai pretest dan posttest dari selisih nilai posttest dan nilai pretest. Terakhir dengan melakukan uji hipotesis untuk mengetahui ada atau tidaknya perbedaan hasil belajar antara kelas eksperimen dan kelas kontrol.

\section{HASIL PENELITIAN DAN PEMBAHASAN}

Merujuk pada rata-rata hasil belajar pre-test dan post-test, dapat disimpulkan bahwa skor rata-rata pre test pada kelas eksperimen adalah 50,78 dan pada kelas kontrol adalah 53,86 . Sedangkan rata-rata post test pada kelas kontrol adalah 82,86 pada kelas eksperimen adalah 84,28 .

Dari uji normalitas pre test dengan kelas eksperimen didapat hasil, yaitu D hitung $=0.13985$ dan nilai $\mathrm{D}$ tabel $=0.14767$ dengan $\alpha=0,05$. Dapat disimpulkan bahwa $\mathrm{D}$ hitung $<$ D tabel $(0.13985<0.14767)$ dan menunjukkan bahwa data variabel berdistribusi normal. Hasil uji normalitas pre test dengan kelas kontrol didapat hasil, yaitu D hitung $=0.14420$ dan nilai $\mathrm{D}$ tabel $=0.14767$ dengan $\alpha=0,05$. Dapat disimpulkan bahwa $\mathrm{D}$ hitung $<$ D tabel $(0.14420<0.14767)$ dan menunjukkan bahwa data variabel berdistribusi normal.

Terdapat pula hasil homogenitas dari data dengan hasil $\mathrm{F}_{\text {hitung }}=0.4553$ dan $\mathrm{F}_{\text {tabel }}=0.5691$. berdasarkan perolehan nilai diatas didapatkan $\mathbf{F}_{\text {hitung }}<\mathbf{F}_{\text {tabel. }}$. Maka dapat disimpulkan bahwa kedua kelas ini dinyatakan homogen.

Hasil uji beda $(\mathrm{t})$ pada pre test menunjukkan $\mathrm{t}_{\text {hitung }}=15,6819$ dan $\mathrm{t}_{\text {tabel }}=1,6669$. Berdasarkan hasil tersebut diketahui $\mathrm{t}_{\text {hitung }}<\mathrm{t}_{\text {tabel, }}$ maka dapat disimpulkan tidak terdapat perbedaan yang signifikan antara kelas eksperimen dengan kelas kontrol, sehingga dapat dikatakan bahwa kemampuan awal siswa adalah sama atau setara.

Lalu, untuk hasil uji beda $(\mathrm{t})$ pada post test menunjukkan $t_{\text {hitung }}=16,3859$ dan $t_{\text {tabel }}=$ 1,6669. Berdasarkan hasil tersebut diketahui $t_{\text {hitung }}<t_{\text {tabel, }}$ maka dapat disimpulkan terdapat perbedaan hasil post-test yang signifikan antara kelas eksperimen dan kelas kontrol.

Selanjutnya, rata-rata analisis Gain pada kelas eksperimen yang menggunakan model pembelajaran kooperatif tipe spontaneous group discussion sebesar 33,50. Nilai ternormalisasi (N-Gain) pada kelas eksperimen dengan model pembelajaran spontaneous group discussion sesuai dengan kriteria indeks gain berada kategori tinggi dengan N-Gain sebesar 0,7329 .

Rata-rata analisis Gain pada kelas kontrol yang menggunakan model pembelajaran kooperatif tipe numbered heads together sebesar 22,41. Nilai ternormalisasi (N-Gain) pada kelas kontrol dengan model pembelajaran numbered heads together sesuai dengan kriteria indeks gain berada kategori sedang dengan N-Gain sebesar 0,6942.

Adapun pengujian hipotesis merupakan langkah terakhir untuk mengambil kesimpulan mengenai ada atau tidaknya perbedaan antara kedua model pembelajaran terhadap hasil belajar. Hasil perhitungan uji hipotesis menggunakan uji-t dengan hasil sebagai berikut.

Tabel 2

Hasil Uji-t Hipotesis

\begin{tabular}{|l|l|c|c|c|}
\hline Kelas & $\mathbf{N}$ & \multicolumn{1}{|l|}{$\mathbf{t}_{\text {hitung }}$} & $\mathbf{t}_{\text {tabeel }}$ & Kesimpulan \\
\cline { 1 - 2 } Eksperimen & 36 & 4,7273 & 1,6669 & $\mathrm{H}_{1}$ diterima \\
\cline { 1 - 2 } Kontrol & 36 & & & \\
\hline
\end{tabular}

Berdasarkan uji-t pada tabel diatas diperoleh $t_{\text {hitung }}=4,7273$ dan $t_{\text {tabeel }}=1,6669$ dari hasil tersebut dapat diketahui bahwa $t_{\text {hitung }}>t_{\text {tabel }}$ dengan taraf kepercayaan sebesar $\alpha=0,05$, sehingga dapat disimpulkan bahwa $\mathrm{H}_{0}$ dan $\mathrm{H}_{1}$ diterima yang berarti terdapat perbedaan peningkatan hasil belajar siswa antara kelas yang menggunakan model pembelajaran 
spontaneous group discussion dengan kelas yang menggunakan model pembelajaran numbered heads together.

\section{KESIMPULAN}

Dari penelitian dan analisis yang dilakukan didapat bahwa terdapat perbedaan hasil belajar antara kelas eksperimen yang menerima treatment model pembelajaran spontaneous group discussion dan kelas kontrol yang menerima treatment model pembelajaran numbered heads together. Model pembelajaran kooperatif tipe spontaneous group discussion lebih cocok untuk diterapkan pada mata pelajaran kearsipan dengan kompetensi dasar mengelola sistem kearsipan pada kelas X program keahlian Administrasi Perkantoran di sebuah SMK Negeri di Kabupaten Karawang. Dari hasil penelitian didapat bahwa model pembelajaran kooperatif tipe spontaneous group discussion rujukan bagi guru Administrasi Perkantoran dalam meningkatkan hasil belajar siswa khususnya pada mata pelajaran kearsipan.

\section{DAFTAR PUSTAKA}

Agus, S. (2010). Cooperative Learning. Yogyakarta: Pustaka Belajar.

Anas Sudijono. 2011. Pengantar Evaluasi Pendidikan. PT. Raja Grafindo.Persada. Jakarta

Arikunto, Suharsimi. (2002). Prosedur Penelitian: Suatu Pendekatan Praktek. Jakarta: Rineka Cipta.

Arikunto, Suharsimi. 2002. Penelitian Tindakan Kelas. Jakarta : PT. Bumi Aksara.

Arikunto, Suharsimi. 2006. Prosedur Penelitian Suatu PendekatanPraktek. Jakarta : Rineka Cipta.Al-Qur'an surat Al-Tin ayat 4.Alfabeta.

Djamarah .(2000). Strategi Belajar Mengajar. Jakarta: Rieneka Cipta.

Huda, Miftahul. (2013). Model-Model Pengajaran dan Pembelajaran.Yogyakarta: Pustaka Pelajar

Isjoni.(2007). Cooperatif Learning Efektivitas Pembelajaran Kelompok. Pekan Baru: Alfabeta

Isjoni. 2010. Cooperatif Learning, Efektifitas Pembelajaran Kelompok. Bandung: Pustaka Pelajar

Joyce, Marsha Weil, Emily Calhoun. (2011). Models of Teaching, edisi 8.

Yogyakarta : Pustaka Belajar

Martono, Nanang. 2010. Metode Penelitian Kuantitatif: Analisis Isi dan Analisis Data Sekunder. Jakarta: PT Raja Grafindo Persada

Nurhadi. 2004. Pembelajaran Kontekstual dan Penerapannya dalam BK. Malang : Universitas Negeri Malang.

Ratumanan, T. G. (2004).Belajar dan Pembelajaran. Semarang. Unesa University Press

Somantri, Ating \& Sambas Ali M. (2006).Aplikasi Statitika. Bandung: Pustaka Setia 
Sudjana, Nana. 2009. Dasar-dasar Proses Belajar Mengajar. Bandung : Sinar Baru Algesindo.

Sudjana, Nana. 2004. Penilaian Hasil Proses Belajar Mengajar. Bandung : PT. Remaja Rosdakarya.

Sugiyono.(2012). Statistik untuk Penelitian.Bandung : Alphabeta.

Syamsudin, Abin. (2005). Psikologi Kependidikan.Bandung : PT Remaja Rosda Karya

Syah, Muhibbin. (2008) Psikologi Belajar.Bandung: Rosdakarya.

Trianto. 2010. Mendesain Model Pembelajaran Inovatif- ProgesifJakarta : Kencana. 